\title{
Dynamic Analysis of Growth, Water Balance and Sap Fluxes through Phloem and Xylem in a Tomato Fruit : Short-term Effect of Water Stress
}

\author{
Takuya AraKI, ${ }^{1}$ Toshihiko EgUChI, ${ }^{2}$ Takahiro WAJIMA, ${ }^{3}$ \\ Satoshi YoshidA ${ }^{2}$ and Masaharu KITANO ${ }^{3}$ \\ ${ }^{1}$ Faculty of Agriculture, Kyushu University, Fukuoka 812-8581, Japan \\ ${ }^{2}$ Biotron Institute, Kyushu University, Fukuoka 812-8581, Japan \\ ${ }^{3}$ Faculty of Agriculture, Kochi University, Nankoku 783-8502, Japan
}

(Received May 18, 2004)

\begin{abstract}
In order to examine the short-term response of tomato (Lycopersicon esculentum Mill.) plants to water stress, we investigated the dynamics of fruit growth and water balance in growing fruits under the well-watered and the water deficit conditions. Under the well-watered condition, most (84\%) of pedicel sap flux toward the fruit contributed to fruit expansion, and the residual (i.e. only 16\%) was lost by transpiration from the fruit and its calyx. The most dominant component of the fruit water balance was the phloem sap flux, since a major part (i.e. 70\%) of the sap delivered into the fruit was brought by phloem transport. On the other hand, xylem transport made a lesser contribution to the fruit expansion and exhibited larger susceptibleness to water stress. Under the water deficit condition, the fruit growth rate was depressed to $36 \%$ of well-watered plants, while phloem sap influx to the fruit was less affected. Xylem sap backflow occurred frequently under the water deficit condition, and the net influx of xylem sap during the whole day was nearly zero. The phloem transport solely sustained the fruit growth under water stress. This study quantitatively demonstrated that water deficit results in smaller fruits with higher sugar concentrations through different responses of phloem and xylem transport to water stress.
\end{abstract}

Keywords : fruit growth, fruit water balance, Lycopersicon esculentum Mill., phloem sap flux, xylem sap flux

\section{INTRODUCTION}

Tomato (Lycopersicon esculentum Mill.) fruit production depends on the accumulation of mass (i.e. water, sugar, calcium ion etc.) in the fruit through phloem and xylem transport. The water accumulation in the fruit is responsible for fruit expansive growth that is variable according to balance between sap flux into the fruit through vascular system and transpiratory water loss from the fruit. Sugar accumulation in the fruit depends on translocation of photoassimilates from leaves through phloem. Accumulation of calcium, which is absorbed by roots and partitioned through vascular system, is also essential for fruit growth as its deficiency results in a high incidence of blossom-end rot.

Phloem transport to sink organs has been considered to be brought by pressure flow

Corresponding author: Takuya Araki, fax : +81-92-642-2833,

e-mail : araki@agr.kyushu-u.ac.jp 
driven by pressure potential gradient along phloem, which is supported by loading and reloading of photoassimilates and osmotic influx of water into sieve tubes (e.g. Münch, 1926 ; Milburn, 1975; Smith et al., 1980). Xylem transport to sink organs is regulated through competitive acquisition of xylem sap by sink organs and transpiring leaves (e.g. Kramer and Boyer, 1995). Thus, water relations affect sink growth and mass accumulation in sink organs through changes in phloem and xylem sap fluxes. In tomatoes, changes in xylem water potential and stem expansion affect dynamics of fruit growth (Johnson et al., 1992; Kitano et al., 1996a, b), and water deficit and high salinity in root region result in growth depression and calcium deficiency in fruits (Ehret and Ho, 1986 ; Ho et al., 1987, 1993, 1995 ; Mitchell et al., 1991a, b ; Adams and Ho, 1993; Araki et al., 1998). Furthermore, fruit respiration can affect post-phloem transport in the fruit, i.e. sugar transport from unloading sites to storage cells of pericarp tissues (Ruan and Patrick, 1995; Ruan et al., 1997). Therefore, simultaneous measurement of dynamics of expansive growth, water balance, phloem sap and xylem sap fluxes, transpiration and respiration in intact tomato fruits is essential for quantitative analyses of environmental effects on mass accumulation in the fruits.

We have already developed a multiple chamber system for on-line and non-contact measurement of growth rate, transpiratory $\mathrm{H}_{2} \mathrm{O}$ efflux and respiratory $\mathrm{CO}_{2}$ efflux in growing tomato fruits (Araki et al., 1998). However, the individual evaluations of phloem sap and xylem sap fluxes through the pedicel have remained impossible. For the individual evaluations of phloem sap and xylem sap fluxes, the heat-ring method might be applicable. The heat-ring method killing phloem cells has been used to inhibit phloem transport through stem, petiole, peduncle and pedicel (Neales and Incoll, 1968 ; Ehret and Ho, 1986; Grusk et al., 1990 ; Lang, 1990 ; Goldschmidt and Huber, 1992 ; Tazuke and Sakiyama, 1993), and it can be applied to the individual evaluations of phloem sap and xylem sap fluxes (Lang, 1990).

In the present paper, the heat-ring method was applied for the individual evaluations of phloem sap and xylem sap fluxes to a growing tomato fruit with a cooperative application of the multiple chamber system, and the short-term effects of water deficit on dynamics of fruit growth and water balance in the fruit were analyzed in relation to phloem and xylem transport.

\section{MATERIALS AND METHODS}

Plant materials and experimental conditions. Young seedlings of tomato (cv. Hausumomotaro) were planted in hydroponic pots $(13 \mathrm{~L})$ filled with the nutrient solution containing $\mathrm{NO}_{3}{ }^{-} 7.6 ; \mathrm{NH}_{4}{ }^{+} 0.8, \mathrm{H}_{2} \mathrm{PO}_{4}^{-} 0.8, \mathrm{~K}^{+} 0.9, \mathrm{Ca}^{2+} 1.8 \mathrm{mmol} \mathrm{L}^{-1}$ with iron EDTA, micronutrients and sufficient supply of dissolved $\mathrm{O}_{2}$. The seedlings were grown in a phytotron at a day/night air temperature of $23 / 18^{\circ} \mathrm{C}$ and a relative humidity of $70 \%$. At the stage of the first truss anthesis, plants were pinched at two leaves above the first truss, then the number of fruits in the truss was thinned to three. About 21 to 25 days after anthesis of the fruits on the first truss, i.e. at the stage of rapid sugar accumulation (Ho et al., 1987), six plants were transferred from the phytotron to a walk-in type growth cabinet where the air condition was set at a day/night air temperature of $25 / 15^{\circ} \mathrm{C}$, a relative humidity of $70 \%$ and a $\mathrm{CO}_{2}$ gas concentration of $370 \mu \mathrm{mol} \mathrm{mol}^{-1}$ under the artificial light of metal halide lamps (DR400/T, Toshiba Corp., Tokyo) with a PPFD of $300 \mu \mathrm{mol} \mathrm{m}{ }^{-2} \mathrm{~s}^{-1}$ in a photoperiod of $12 \mathrm{~h}\left(6: 00^{-}\right.$ 18:00). After 2 days acclimation of the plants to the growth cabinet condition, on-line evaluation of fruit growth rate, sap fluxes, $\mathrm{H}_{2} \mathrm{O}$ and $\mathrm{CO}_{2}$ gas fluxes in the intact fruit was started at midnight.

The measurements were made on the plants under the complete well-watered and the water deficit conditions. The water deficit condition was made by dewatering hydroponic 
pots at the start of the experiment while pots in the well-watered condition were kept full of nutrient solution. The duration of the water stress was about 1 day. The water stress was severe as the leaf to wilt, but the damage was not lethal because the leaf soon recovered from the wilting by rewatering at the end of the experiment.

Gas exchange measurement with a multiple chamber system. The fruit growth rate, a transpiratory $\mathrm{H}_{2} \mathrm{O}$ efflux and a respiratory $\mathrm{CO}_{2}$ efflux in the intact fruits, and a transpiratory $\mathrm{H}_{2} \mathrm{O}$ efflux and a photosynthetic $\mathrm{CO}_{2}$ influx in the intact leaflets were measured on-line using the multiple chamber system (Araki et al., 1998). Figure 1 shows a schematic diagram of the system for simultaneous measurement of the fruit growth and the gas exchange for six plants. An intact fruit or an intact leaflet was enclosed in each chamber. Each chamber was temporarily kept as "closed system," and changing rates of $\left[\mathrm{CO}_{2}\right]$ and $\left[\mathrm{H}_{2} \mathrm{O}\right]$ were measured on-line. In this study, the gas fluxes from the fruit including those from the calyx and the pedicel enclosed in the fruit chamber, and the respiratory $\mathrm{CO}_{2}$ efflux $\left(J_{\mathrm{CF}} ; \mathrm{mol} \mathrm{cm} \mathrm{cs}^{-3}\right)$ and the transpirational $\mathrm{H}_{2} \mathrm{O}$ efflux $\left(J_{\mathrm{WF}} ; \mathrm{m}^{3} \mathrm{~m}^{-3} \mathrm{~s}^{-1}\right)$ were represented as the values per unit fruit volume. The gas fluxes in the leaflet, i.e. photosynthetic $\mathrm{CO}_{2}$ influx $\left(-J_{\mathrm{CL}} ; \mathrm{mol} \mathrm{m}^{-2} \mathrm{~s}^{-1}\right)$ and transpirational $\mathrm{H}_{2} \mathrm{O}$ efflux $\left(J_{\mathrm{wL}} ; \mathrm{mol} \mathrm{m}^{-2} \mathrm{~s}^{-1}\right)$, were represented as the values per unit leaf area.

Measurement of fruit growth rate and pedicel sap flux. Each fruit chamber in the multiple chamber system was equipped with a pair of laser displacement sensors (LDS; Z4M-W40, OMRON Corp., Kyoto) for on-line and non-contact measurement of fruit growth rate (Fig. 1). Fruit diameter was measured on-line every $1 \mathrm{~min}$ by the LDS system with a resolution of $1.5 \mu \mathrm{m}$, and relative growth rate $\left(G R F ; \mathrm{m}^{3} \mathrm{~m}^{-3} \mathrm{~s}^{-1}\right)$ of the fruit on a volume basis was evaluated by the following relationship : $V_{\mathrm{F}}=0.4177 D_{\mathrm{F}}^{3}+1.932\left(r^{2}=0.98^{* * *}\right), V_{\mathrm{F}}\left(\mathrm{m}^{3}\right)$, fruit volume, $D_{\mathrm{F}}(\mathrm{m})$, fruit diameter (Kitano et al., 1996a). Based on water balance in the fruit, $G R F$, i.e. volume increment of the fruit, is estimated to be equivalent to difference between pedicel sap flux $\left(J_{\mathrm{Sap}} ; \mathrm{m}^{3} \mathrm{~m}^{-3} \mathrm{~s}^{-1}\right)$ toward the fruit and transpiratory water loss $\left(J_{\mathrm{WF}}\right.$; $\left.\mathrm{m}^{3} \mathrm{~m}^{-3} \mathrm{~s}^{-1}\right)$ from the fruit. Therefore, $J_{\mathrm{Sap}}$ can be evaluated by the sum of $G R F$ and $J_{\mathrm{WF}}$ measured in the fruit chamber as

$$
J_{\mathrm{Sap}}=G R F+J_{\mathrm{WF}}
$$

These variables $\left(G R F, J_{\mathrm{WF}}\right.$ and $\left.J_{\mathrm{Sap}}\right)$ in the intact fruit were represented as the values per unit fruit volume.

Individual evaluations of phloem sap and xylem sap fluxes. The pedicel sap flux $\left(J_{\text {Sap }}\right)$ is composed of phloem sap flux $\left(J_{\mathrm{Phlo}} ; \mathrm{m}^{3} \mathrm{~m}^{-3} \mathrm{~s}^{-1}\right)$ and xylem sap flux $\left(J_{\mathrm{Xy}} ; \mathrm{m}^{3} \mathrm{~m}^{-3} \mathrm{~s}^{-1}\right)$ as

$$
J_{\mathrm{Sap}}=J_{\mathrm{Phlo}}+J_{\mathrm{xy}}
$$

For the individual evaluations of $J_{\text {Phlo }}$ and $J_{\mathrm{xy}}$, phloem transport through the peduncle was blockaded by the heat-ring treatment. In the measurement with the multiple chamber system for six plants, three plants were treated with the heat-ring at the basal site of the peduncle of the first truss. A gauze band of $1 \mathrm{~cm}$ width was attached around the basal site of the peduncle, and $90^{\circ} \mathrm{C}$ hot water was dripped onto the gauze band for $1 \mathrm{~h}$ from the start of the experiments at midnight. A number of studies demonstrated that the heat-ring treatments $\left(>60^{\circ} \mathrm{C}\right)$ inhibit phloem transport by killing phloem cells without significant effect on xylem water transport for leaf transpiration (Neales and Incoll, 1968 ; Ehret and Ho, 1986 ; Grusk et al., 1990 ; Lang, 1990 ; Goldschmidt and Huber, 1992 ; Tazuke and Sakiyama, 1993). Therefore, pedicel sap flux on the heat-ringed peduncle $\left(J_{\text {Sap }}^{\prime} ; \mathrm{m}^{3} \mathrm{~m}^{-3} \mathrm{~s}^{-1}\right)$ was considered to be brought through xylem transport only and to be equivalent to $J_{\mathrm{xy}}$ on the non-heat-ringed peduncle as

$$
J^{\prime}{ }_{\text {Sap }}=J_{\mathrm{Xy}}
$$

$J^{\prime}$ sap can be also evaluated on the basis of Eq. (1) as 


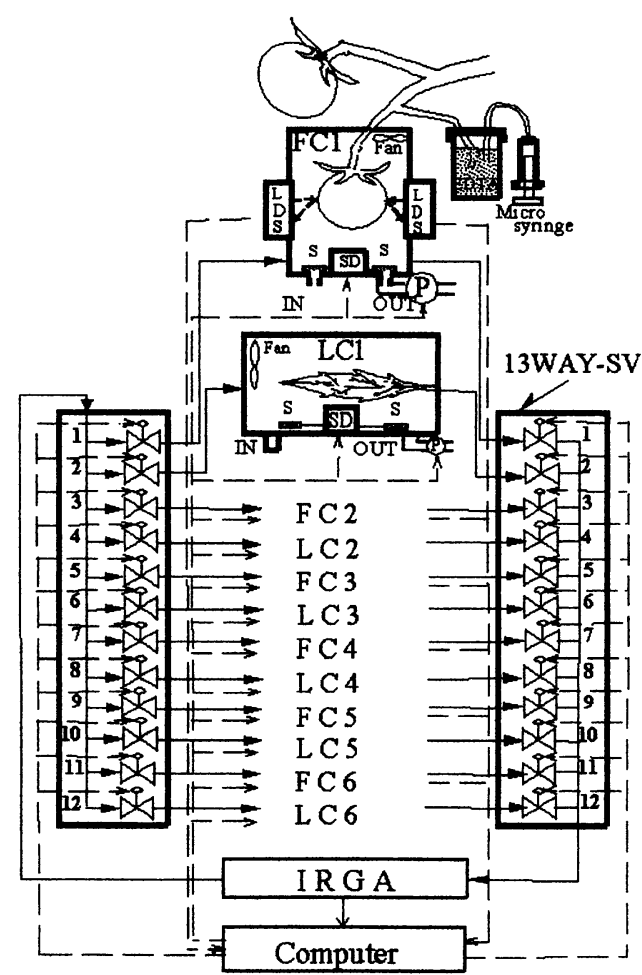

Fig. 1 Schematic diagram of a multiple chamber system for measuring growth rate, transpiratory $\mathrm{H}_{2} \mathrm{O}$ efflux and respiratory $\mathrm{CO}_{2}$ efflux in intact fruits and transpiratory $\mathrm{H}_{2} \mathrm{O}$ efflux and photosynthetic $\mathrm{CO}_{2}$ influx in intact leaflets of tomato plants. In the systems, six fruit chambers and six leaf chambers for the intact fruits and leaflets can be connected in parallel with an infrared $\mathrm{CO}_{2}$ and $\mathrm{H}_{2} \mathrm{O}$ gas analyzer through a pair of 13-way solenoid valves. FC1-FC6, fruit chambers; IN, air inlet of the ventilating openings; IRGA, infrared $\mathrm{CO}_{2}$ and $\mathrm{H}_{2} \mathrm{O}$ gas analyzer; LC1-LC6, leaf chambers; LDS, laser displacement sensor; OUT, air outlet of the ventilating openings; $\mathrm{P}$, air pump for ventilating each chamber; $\mathrm{S}$, shutter of the ventilating openings; $\mathrm{SD}$, servomotor for driving the shutters; 13-WAY SV, 13-way solenoid valves; solid line, air sampling path ; broken line, signal path.

$$
J^{\prime}{ }_{\text {Sap }}=G R F^{\prime}+J^{\prime}{ }_{\text {wF }}
$$

where $G R F^{\prime}$ and $J^{\prime}{ }_{\mathrm{WF}}$ are $G R F$ and $J_{\mathrm{WF}}$ measured on the heat-ringed peduncle by using the multiple chamber system, respectively. Therefore, from Eqs. (2) and (3), phloem sap flux $\left(J_{\text {Phlo }}\right)$ through the pedicel on the non-heat-ringed peduncle can be evaluated by difference between $J_{\text {Sap }}$ on the non-heat-ringed peduncle and $J^{\prime}$ sap on the heat-ringed peduncle as

$$
J_{\text {Phlo }}=J_{\text {Sap }}-J_{\text {Sap }}^{\prime}
$$

Verification of the heat-ring method. For reliable application of the heat-ring method to the individual evaluations of $J_{\mathrm{Phlo}}$ and $J_{\mathrm{xy}}$, it is necessary to verify that the heat-ring treatment on the peduncle can inhibit phloem transport through the pedicel without significant effect on xylem transport of water for fruit transpiration. Therefore, phloem transport of sugars through the pedicel and fruit transpiratory $\mathrm{H}_{2} \mathrm{O}$ efflux of the heat-ringed plants were compared with those of the non-heat-ringed plants. The sugar flux exuded through the cut end of a pedicel was evaluated by applying the ethylenediaminetetraacetic acid (EDTA) 
method established in the previous study (Araki et al., 1997a): The pedicel cut end was immersed into $20 \mathrm{~mm}$ EDTA solution of $1,000 \mu \mathrm{l}$ in a vial, and partial sampling (500 $\mu \mathrm{l})$ of the solution in the vial loaded with exuded sugars and replenishing the vial with the fresh EDTA solution were repeated at intervals of $30 \mathrm{~min}$. Concentrations of sugars (sucrose, glucose and fructose) in the sampled solution were determined by high performance liquid chromatography (LC-10AD, SHIMADZU Corp., Kyoto) with a stylenedivinylbenzene copolymer column (Shim-pack SCR-101N, SHIMADZU Corp.) and a differential refractometer (RID-6A, SHIMADZU Corp.). The sugar flux exuded through the pedicel cut end was evaluated by changes on sugar concentration and volumes of each sampled and replenished solution. The sugar fluxes evaluated for the non-heat-ringed plant and for the heat-ringed plant were converted into carbon-based photoassimilate flux represented as the $J_{\mathrm{CP}}\left(\mathrm{nmol}^{-1}\right)$ and $J_{\mathrm{CP}}^{\prime}$ $\left(n \mathrm{nol}^{-1}\right)$, respectively. Furthermore, the fruit transpiratory $\mathrm{H}_{2} \mathrm{O}$ efflux (i.e. $J_{\mathrm{wF}}$ on the non-heat-ringed peduncle and $J_{\text {WF }}^{\prime}$ on the heat-ringed peduncle) was measured by using the multiple chamber system.

is

\section{RESULTS}

\section{Heat-ring treatment}

Figure 2 shows diurnal patterns of $J_{\mathrm{CP}}$ and $J_{\mathrm{WF}}$ on the non-heat-ringed peduncle and $J_{\mathrm{CP}}^{\prime}$ and $J^{\prime}{ }_{\mathrm{WF}}$ on the heat-ringed peduncle. $J_{\mathrm{CP}}$ on the non-heat-ringed peduncle rapidly rose just after lighting and kept remarkably higher than that in the dark period. This rise in sugar flux under the light was strictly inhibited by the heat-ring treatment, and $J_{\mathrm{CP}}^{\prime}$ on the heat-ringed peduncle remained nearly zero irrespective of lighting. The transpiratory $\mathrm{H}_{2} \mathrm{O}$ efflux rose rapidly just after lighting in both of the heat-ringed and the non-heat-ringed peduncles, and

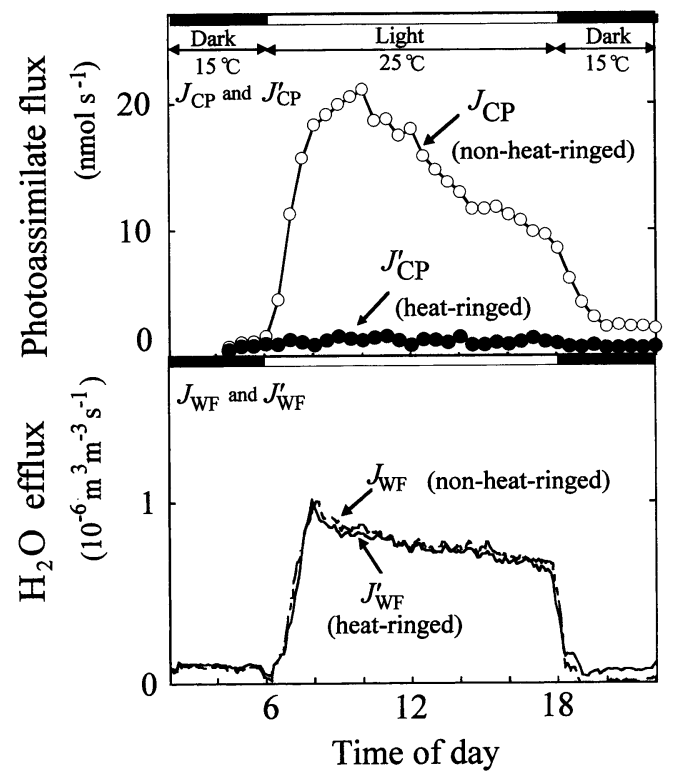

Fig. 2 Diurnal patterns of photoassimilate flux through a pedicel cut end and transpiration rate from an intact fruit on the non-heat-ringed peduncle and on the heat-ringed peduncle. $J_{\mathrm{CP}}$, photoassimilate flux (carbon flux) through a pedicel cut end on the non-heat-ringed peduncle; $J_{\mathrm{WF}}$, transpiratory $\mathrm{H}_{2} \mathrm{O}$ efflux per unit fruit volume in an intact fruit with calyx and pedicel on the non-heat-ringed peduncle; $J_{\mathrm{CP}}^{\prime}$ and $J_{\mathrm{WF}}^{\prime}, J_{\mathrm{CP}}$ and $J_{\mathrm{WF}}$ on the heat-ringed peduncle, respectively. 


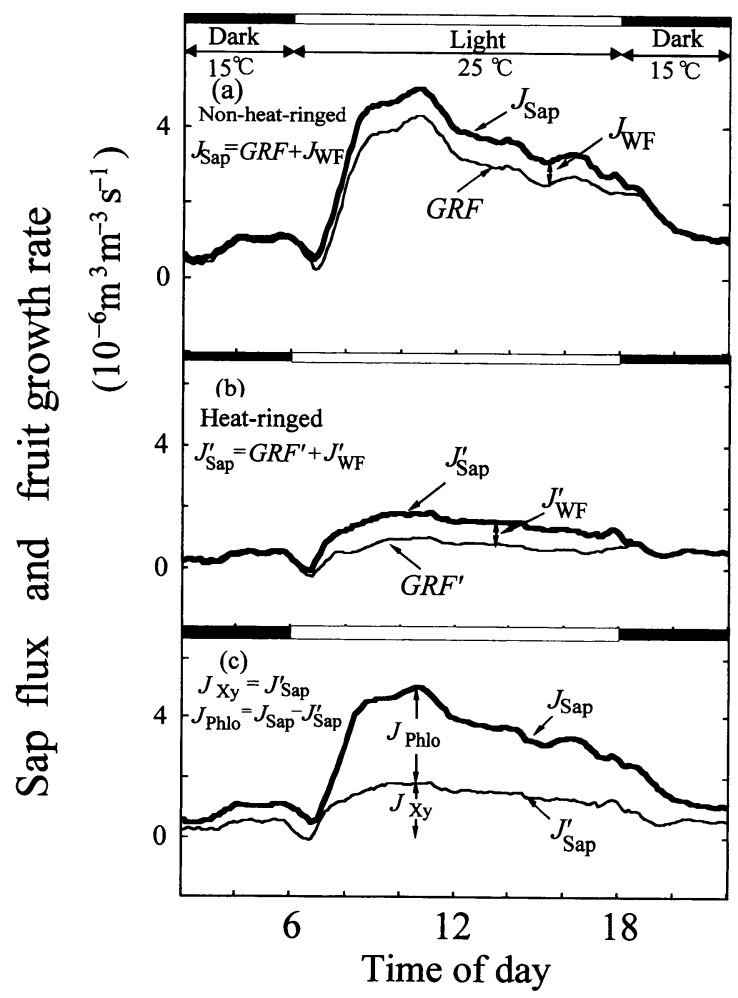

Fig. 3 Diurnal patterns of fruit growth rate and pedicel sap flux on the non-heat-ringed peduncle (a) and on the heat-ringed peduncle (b), and individual evaluations of phloem sap flux and xylem sap flux through a pedicel under the well-watered condition (c). $G R F, J_{\mathrm{Sap}}$ and $J_{\mathrm{WF}}$, fruit growth rate, pedicel sap flux and transpiratory $\mathrm{H}_{2} \mathrm{O}$ efflux per unit fruit volume in an intact fruit on the non-heat-ringed peduncle. GRF', $J^{\prime}$ sap and $J^{\prime}{ }_{\text {wF }}$, fruit growth rate, pedicel sap flux and transpiratory $\mathrm{H}_{2} \mathrm{O}$ efflux per unit fruit volume in an

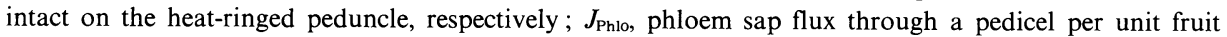
volume on the non-heat-ringed peduncle; $J_{\mathrm{xy}}$, xylem sap flux through a pedicel per unit fruit volume on the non-heat-ringed peduncle.

$J^{\prime}{ }_{\mathrm{WF}}$ on the heat-ringed peduncle remained at almost the same values as $J_{\mathrm{WF}}$ on the non-heatringed peduncle. Thus, the heat-ring treatment on the tomato peduncle can inhibit phloem transport of photoassimilates through the pedicel without significant effect on xylem transport of water for fruit transpiration. Furthermore, effects of the heat-ring treatment on GRF and $J_{\text {Sap }}$ and the individual evaluations of $J_{\text {Phlo }}$ and $J_{\mathrm{xy}}$ were examined under the condition of well-watered (Fig. 3). $G R F^{\prime}$ and $J_{\text {Sap }}^{\prime}$ on the heat-ringed peduncle were significantly depressed as compared with $G R F$ and $J_{\text {Sap }}$ on the non-heat-ringed peduncle, respectively, and the individual evaluations of $J_{\mathrm{Phlo}}$ and $J_{\mathrm{Xy}}$ on the non-heat-ringed peduncle were performed by using Eqs. (3) and (5).

\section{Dynamics of fruit growth and components of fruit water balance}

Under the water deficit condition, midday leaf water potential measured psychrometrically was lowered to $-1.4 \pm 0.2 \mathrm{MPa}$, while it was kept at $-0.6 \pm 0.1 \mathrm{MPa}$ under the well-watered condition. This lowered leaf water potential under water deficit brought significant depression in gas exchange in leaflets (Fig. 4). Transpiratory $\mathrm{H}_{2} \mathrm{O}$ efflux $\left(J_{\mathrm{wL}}\right)$ and photosynthetic $\mathrm{CO}_{2}$ influx $\left(-J_{\mathrm{CL}}\right)$ rose rapidly just after lighting, but this rise was significantly suppressed 


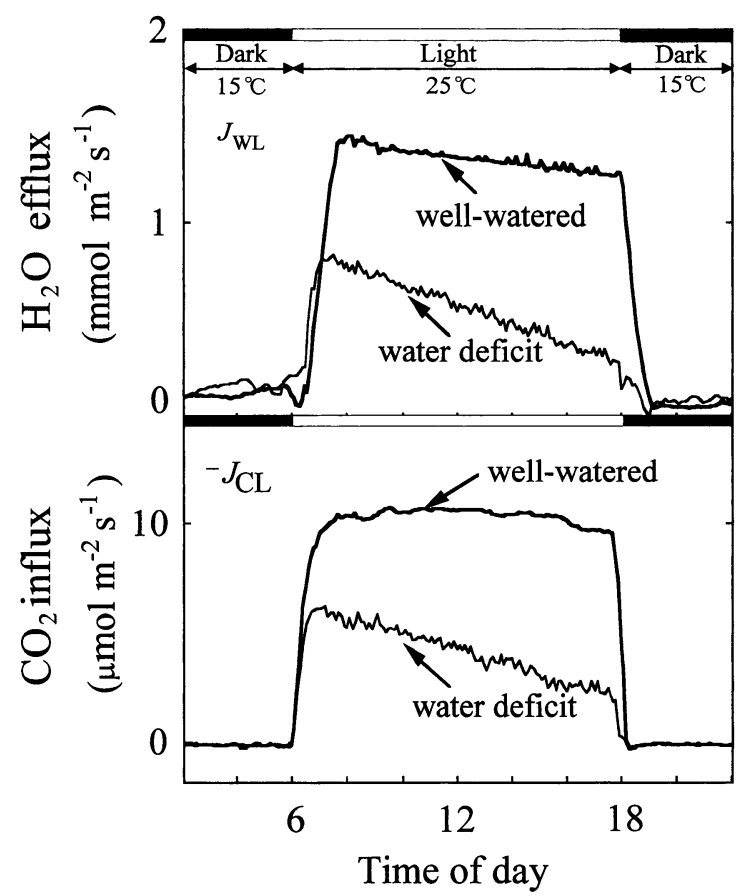

Fig. 4 Diurnal patterns of transpiration rate and photosynthetic rate in an intact leaflet under the respective conditions of well-watered and water deficit. $-J_{\mathrm{CL}}$ and $J_{\mathrm{wL}}$, photosynthetic $\mathrm{CO}_{2}$ influx and transpiratory $\mathrm{H}_{2} \mathrm{O}$ efflux per unit leaf area, respectively.

Table 1 Cumulative gas fluxes in an intact leaflet and a fruit during the light period $(06: 00-18: 00)$, under the conditions of well-watered and water deficit.

\begin{tabular}{lll}
\hline & Well-watered & Water deficit \\
\hline$\sum\left(-J_{\mathrm{CL}}\right)\left(\mathrm{mol} \mathrm{m}^{-2}\right)$ & $0.428 \pm 0.055$ & $0.173 \pm 0.025^{*}$ \\
$\sum J_{\mathrm{WL}}\left(10^{3} \mathrm{~mol} \mathrm{~m}^{-2}\right)$ & $0.053 \pm 0.008$ & $0.024 \pm 0.005^{*}$ \\
$\sum J_{\mathrm{CF}}\left(\mathrm{mmol} \mathrm{cm}^{-3}\right)$ & $0.044 \pm 0.007$ & $0.032 \pm 0.005^{*}$ \\
$\sum J_{\mathrm{WF}}\left(\mathrm{cm}^{3} \mathrm{~cm}^{-3}\right)$ & $0.023 \pm 0.005$ & $0.012 \pm 0.003^{*}$ \\
\hline
\end{tabular}

$\Sigma\left(-J_{\mathrm{CL}}\right)$ and $\sum J_{\mathrm{WL}}$, integrated photosynthetic $\mathrm{CO}_{2}$ influx and transpirational $\mathrm{H}_{2} \mathrm{O}$ efflux per unit area in an intact leaflet; $\sum J_{\mathrm{CF}}$ and $\sum J_{\mathrm{WF}}$, integrated respiratory $\mathrm{CO}_{2}$ efflux and transpirational $\mathrm{H}_{2} \mathrm{O}$ efflux per unit fruit volume in an intact fruit with calyx and pedicel.

Values are means of three plants.

The significance of differences between well-watered and water deficit conditions was tested by Student's $t$-test, with ${ }^{*}$ for $p=0.05$.

under the water deficit condition, where $\sum J_{\mathrm{WL}}$ and $\Sigma\left(-J_{\mathrm{CL}}\right)$ during the light period were decreased by $60 \%$ and $50 \%$, respectively, as compared with those under well-watered condition (Table 1). The water stress also affected the gas exchange in the fruit (Fig. 5). Diurnal pattern of transpiratory $\mathrm{H}_{2} \mathrm{O}$ efflux $\left(J_{\mathrm{WF}}\right)$ in the fruit was similar to that of $J_{\mathrm{WL}}$ in the leaflet, that is, $J_{\mathrm{WF}}$ rose rapidly just after lighting. This rise by lighting, however, was remarkably suppressed in water deficit plants, which resulted in $50 \%$ decrease in $\sum J_{\mathrm{WF}}$ during the light period as compared with that of well-watered plants (Table 1). Diurnal pattern of respiratory 


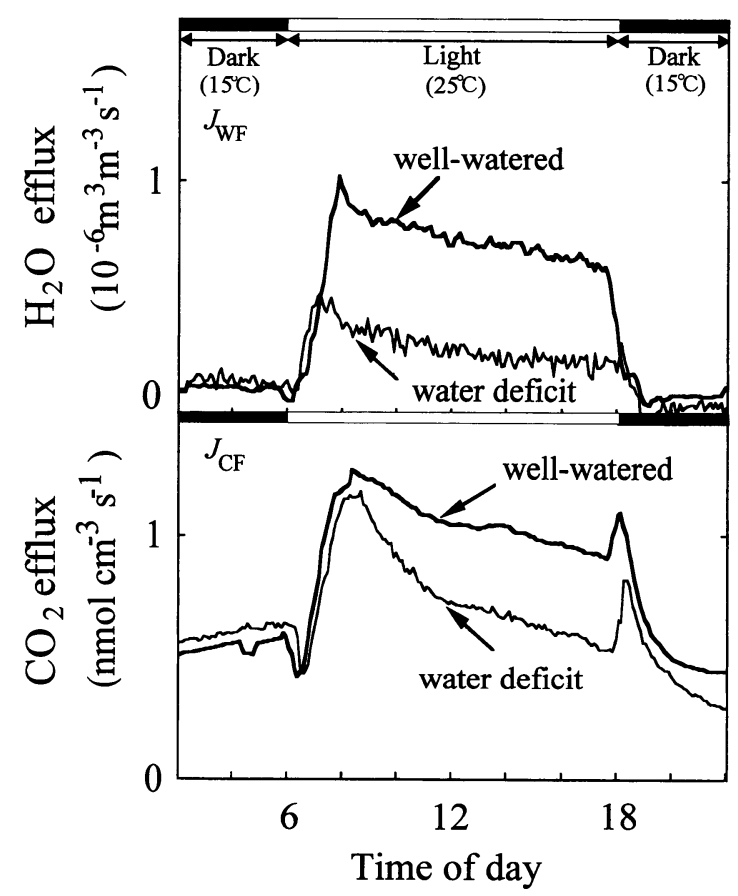

Fig. 5 Diurnal patterns of transpiration rate and respiration rate in an intact fruit with calyx and pedicel under the respective conditions of well-watered and water deficit. $J_{\mathrm{CF}}$ and $J_{\mathrm{WF}}$, respiratory $\mathrm{CO}_{2}$ efflux and transpiratory $\mathrm{H}_{2} \mathrm{O}$ efflux per unit fruit volume, respectively.

$\mathrm{CO}_{2}$ efflux $\left(J_{\mathrm{CF}}\right)$ in the fruit was somewhat different from that in $J_{\mathrm{WF}}$. Just after lighting, a transient drop in $J_{\mathrm{CF}}$ was caused by the start of $\mathrm{CO}_{2}$ absorption for fruit photosynthesis, and immediately $J_{\mathrm{CF}}$ was increased by activation of fruit respiration according to lighting and rise in the ambient air temperature from the night temperature of $15^{\circ} \mathrm{C}$ to the day temperature of $25^{\circ} \mathrm{C}$. In about $2 \mathrm{~h}$, this increasing $J_{\mathrm{CF}}$ reached the maximum, which was about two times higher than that before the light period. Thereafter, $J_{\mathrm{CF}}$ of water deficit plants significantly decreased to the level before lighting, while $J_{\mathrm{CF}}$ of well-watered plants was kept twice as high as that before lighting. Consequently under the water deficit condition $\sum J_{\mathrm{CF}}$ during the light period was decreased by $40 \%$ as compared with that under well-watered condition (Table 1). When the light was turned off, $J_{\mathrm{CF}}$ transiently rose because of the cessation of $\mathrm{CO}_{2}$ absorption for fruit photosynthesis, but air temperature drop from the day temperature of $25^{\circ} \mathrm{C}$ to the night temperature of $15^{\circ} \mathrm{C}$ turned down fruit respiration, resulting in significant decrease in $J_{\text {CF. }}$. Evidently, the water deficit condition significantly depressed fruit respiration during the light period as well as fruit transpiration.

Figure 6 shows diurnal pattern of fruit growth rate $(G R F)$ under the respective conditions of well-watered and water deficit. Under the well-watered condition, $G R F$ increased during the light period in response to lighting and air temperature rise from 15 to $25^{\circ} \mathrm{C}$. This sensitiveness of fruit growth to lighting and the temperature rise was strictly restrained by the water deficit, resulting in significantly low $G R F$ under the water deficit condition. Figure 7 shows diurnal patterns of sap fluxes $\left(J_{\mathrm{Sap}}, J_{\text {Phlo }}\right.$ and $\left.J_{\mathrm{Xy}}\right)$ through the pedicel. Under the well-watered condition, sap fluxes through the pedicel were accelerated by lighting and the temperature rise, and this acceleration appeared higher in $J_{\text {Phlo }}$ than in $J_{\mathrm{Xy}}$. The water deficit caused unstable fluctuation and remarkable depression in $J_{\text {Phlo }}$ and $J_{\mathrm{xy}}$. In particular, $J_{\mathrm{xy}}$ 


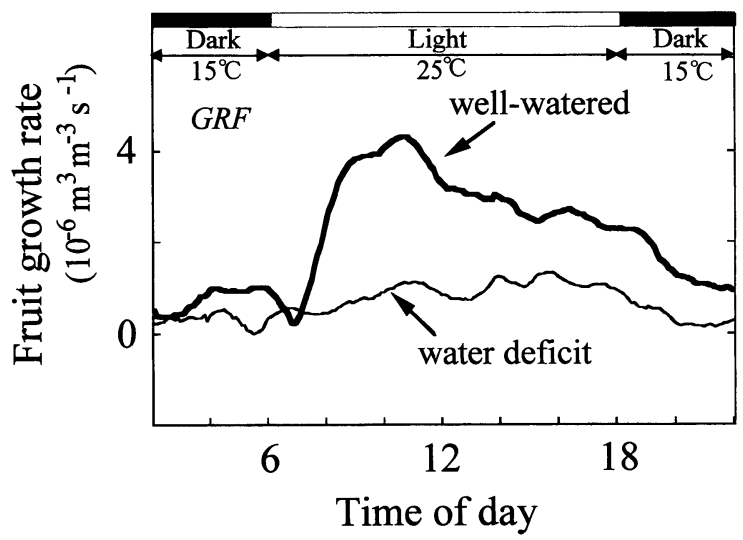

Fig. 6 Diurnal patterns of fruit growth rate under the respective conditions of well-watered and water deficit. $G R F$, fruit growth rate per unit fruit volume.

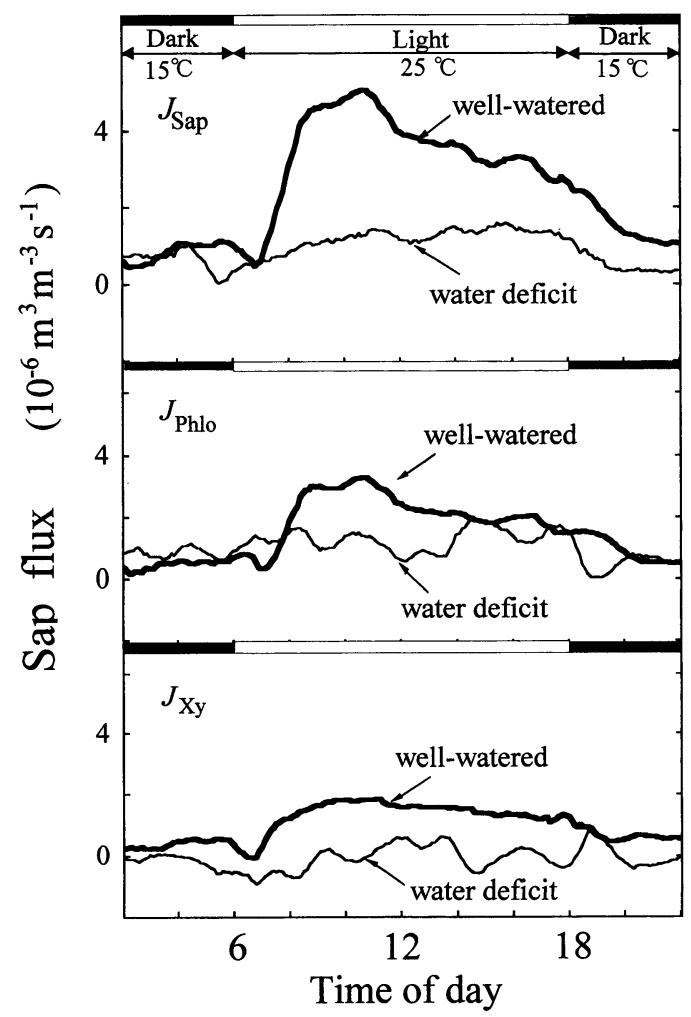

Fig. 7 Diurnal patterns of sap fluxes through a pedicel under the respective conditions of well-watered and water deficit. $J_{\text {Sap }}$, pedicel sap flux via phloem and xylem; $J_{\text {Phlo }}$ and $J_{\mathrm{Xy}}$, phloem sap flux and xylem sap flux through a pedicel, respectively. $J_{\text {Sap }}, J_{\text {Phlo }}$ and $J_{\mathrm{Xy}}$ were evaluated as fluxes per unit fruit volume.

often appeared in negative values, which suggested that sap flowed back from the fruit through xylem. Table 2 shows integrated sap fluxes and fruit growth, i.e. $\sum J_{\mathrm{Sap}}, \sum J_{\mathrm{Phlo}}, \sum J_{\mathrm{Xy}}, \Sigma$ $\left(J_{\mathrm{xy}}>0\right), \Sigma\left(J_{\mathrm{xy}}<0\right), \Sigma G R F$, during the light period, the dark period and the whole day under 


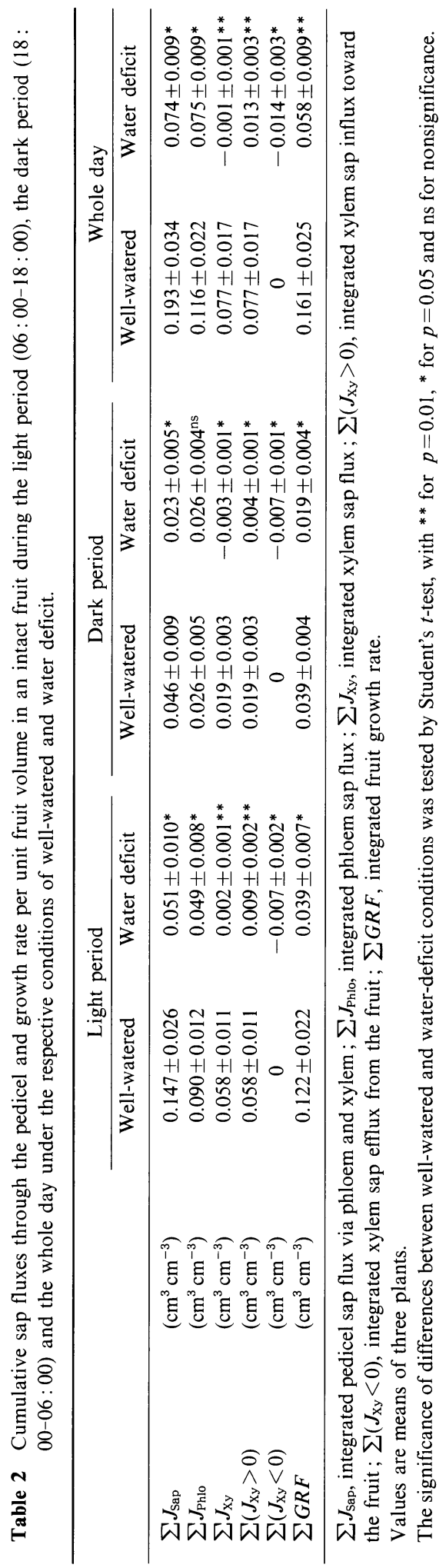


the well-watered and water deficit conditions. Each value of the light period under the well-watered condition was responsible for $75 \%$ to $78 \%$ of $\sum G R F, \sum J_{\text {Sap }}, \sum J_{\text {Phlo }}$ and $\sum J_{\mathrm{xy}}$ during the whole day. Thus, large amounts of sap fluxes and fruit growth were brought during the light period. Under the water deficit condition, $65 \%$ to $69 \%$ of $\sum G R F, \sum J_{\text {Sap }}$ and $\sum J_{\mathrm{Phlo}}$ appeared during the light period, whereas $\sum J_{\mathrm{Xy}}$ integrated during the whole day was decreased to nearly zero. The water deficit decreased xylem sap flux toward the fruit $(\Sigma$ $\left.\left(J_{\mathrm{xy}}>0\right)\right)$ by $83 \%$ and frequently caused sap backflow through xylem (Fig. 7). That is, the xylem sap backflow $\left(\sum\left(J_{\mathrm{xy}}<0\right)\right)$ during the whole day amounted to $-0.014 \mathrm{~cm}^{3} \mathrm{~cm}^{-3}$, which completely offset the xylem sap flux toward the fruit $\left(\sum\left(J_{x y}>0\right)\right)$. On the other hand, sap backflow was not occurred in phloem, and effect of water deficit on $\sum J_{\text {Phlo }}$ amounted to no more than $35 \%$ decrease during the whole day. Consequently, the water deficit brought about $60 \%$ decrease in $\sum J_{\text {Sap }}$ and $\sum G R F$ during the whole day.

We followed the backflow of xylem sap by a dye tracing experiment. Lucifer yellow $\mathrm{CH}$ ( $\mathrm{LYCH}$, Aldrich Chem. Co.), a fluorescent dye, was prepared as a $1 \%(\mathrm{~W} / \mathrm{V})$ aqueous solution, and a slight amount $(<20 \mu \mathrm{L})$ of the solution was introduced into the center of the tomato fruit using a Hamilton micro-syringe (725RN, needle gauge $22 \mathrm{~s})$ in the dark period. The LYCH injection was done for both of well-watered and water deficit plants. The dye-injected fruits were harvested with pedicel and peduncle at $14: 00$ of the next light period. Figure 8 shows microphotographs of the peduncle transactions at about $70 \mathrm{~mm}$ apart from the fruit of water deficit (A) and well-watered (B) plants. In water deficit plant, the intense fluorescence of LYCH was observed in secondary xylem of the peduncle even in the part nearest to stem. On the other hand, the intense fluorescence was not observed in the pedicel and peduncle of well-watered plant. Thus, the centripetal movement of the dye, i.e. xylem sap, was visually confirmed in the peduncle of water deficit plants.

Figure 9 shows components of fruit water balance integrated during the whole day under

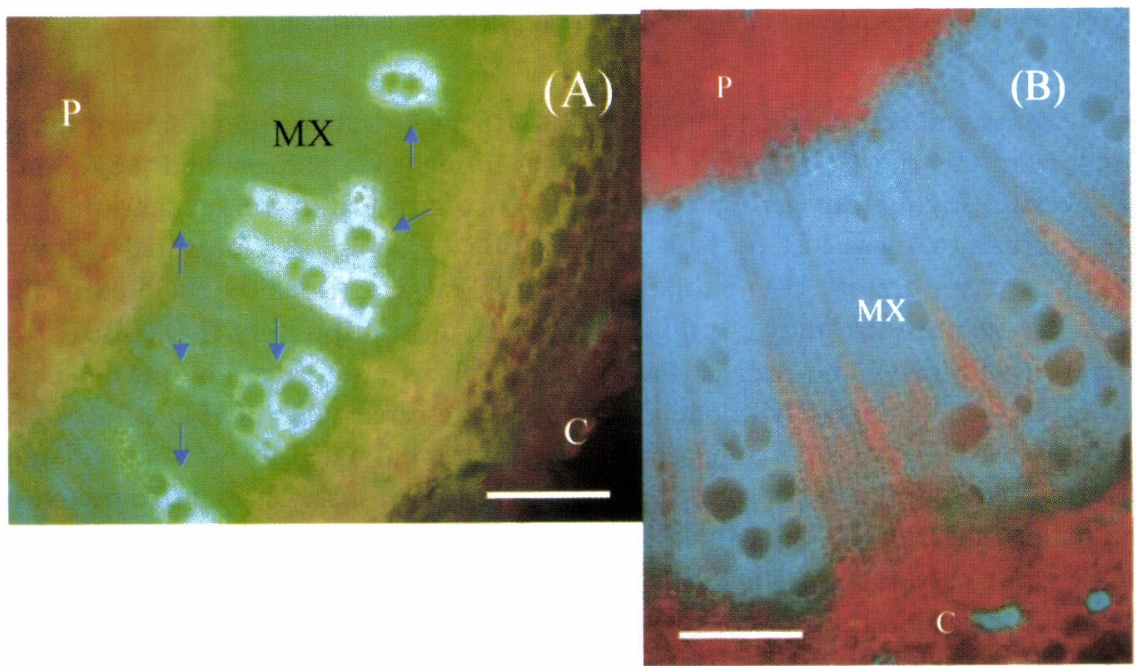

Fig. 8 Peduncle transactions at about $70 \mathrm{~mm}$ apart from the fruit of water deficit (A) and well-watered (B) plants, viewed with the fluorescence microscopy, Nikon microscope (OPTIPHOT-2) with fluorescence attachment (HB-10103AF, Nikon Co.) under blue-violet filter (BV-1 A, dichroic mirror $455 \mathrm{~nm}$, excitation filter 425-445 nm, barrier filter $460 \mathrm{~nm}$, Nikon Co.). C, cortex; MX, metaxylem; P, pith. The intense fluorescence of $\mathrm{LYCH}$ was observed in secondary xylem of the peduncle of the water deficit plants (A), although xylem and cortical fibers showed a weak autofluorescence of pale yellow-green (B). 

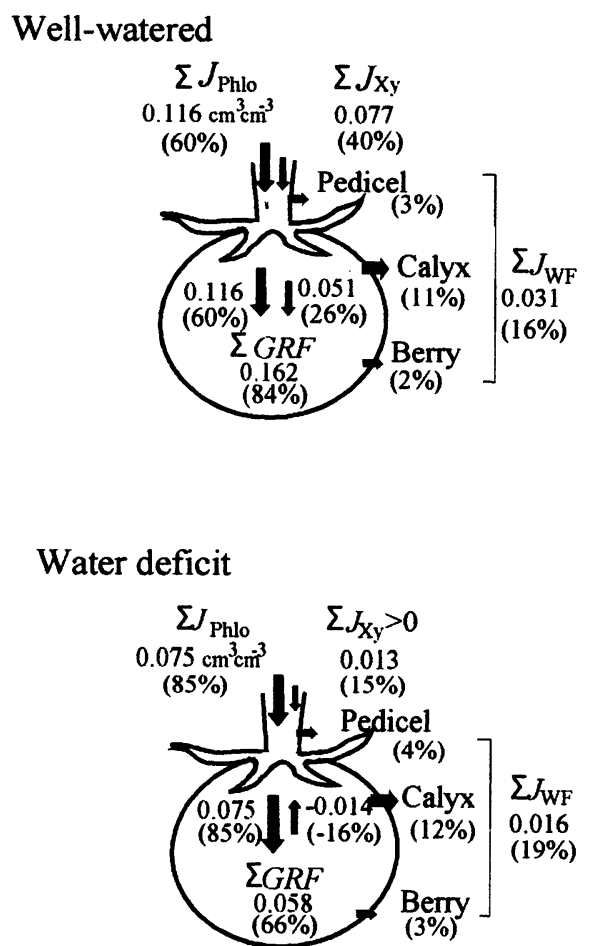

Fig. 9 Cumulative components of water balance in an intact fruit during the whole day under the respective conditions of well-watered and water deficit : $\sum G R F, \sum J_{\mathrm{Phlo}}, \sum J_{\mathrm{xy}}, \sum J_{\mathrm{WF}}$, growth rate, phloem sap flux, xylem sap flux and transpiratory $\mathrm{H}_{2} \mathrm{O}$ efflux per unit fruit volume in an intact fruit integrated during the whole day. Values in parentheses indicate percentages of the respective components to the cumulative sap flux toward the fruit $\left(\sum J_{\mathrm{Phlo}}+\Sigma\left(J_{\mathrm{Xy}}>0\right)\right)$. Dark and gray arrows indicate sap fluxes through phloem and xylem and transpiratory $\mathrm{H}_{2} \mathrm{O}$ efflux, respectively.

the well-watered and water deficit conditions. In the well-watered plant, $60 \%$ of the pedicel sap flux toward the fruit $\left(\sum J_{\text {Phlo }}+\sum\left(J_{\mathrm{xy}}>0\right)\right)$ was brought via phloem, and the residual $40 \%$ was via xylem. Eighty-four percent of the sap flux contributed to fruit expansion $(\Sigma G R F)$, and the residual $16 \%$ was lost by fruit transpiration $\left(\sum J_{\mathrm{WL}}\right)$. $J_{\mathrm{WF}}$ measured in this study consists of the transpiratory $\mathrm{H}_{2} \mathrm{O}$ effluxes from fruit, calyx and pedicel enclosed in the fruit chamber. In the previous study (Araki et al., 1997b), the transpiratory $\mathrm{H}_{2} \mathrm{O}$ effluxes from the attached fruit with calyx and pedicel, the attached fruit without calyx and the detached fruit without calyx were compared with one another, and the percentages of $\mathrm{H}_{2} \mathrm{O}$ effluxes from the respective organs of fruit, calyx and pedicel in $J_{\mathrm{WF}}$ were estimated to be $14 \%, 66 \%$ and $20 \%$, respectively. Based on these percentages, transpiratory water losses from the respective organs of berry, calyx and pedicel were equivalent to $2 \%, 11 \%$ and $3 \%$ of the pedicel sap flux toward the fruit. On the assumption that xylem sap flux through the pedicel supplies water to calyx and pedicel for transpiration, xylem sap flux delivered into the fruit was estimated to be only $26 \%$ of the pedicel sap flux toward the fruit. Consequently, $70 \%$ of sap delivered into the fruit was brought through phloem in well-watered plants. In water deficit plants, $85 \%$ of pedicel sap flux toward the fruit was via phloem, and the sap flux via xylem was only $15 \%$. The pedicel sap flux toward the fruit was allocated to fruit growth by $66 \%$ and to fruit transpiration by $18 \%$. The residual $16 \%$, however, was estimated to flow out of the fruit through xylem. Therefore, a net sap influx to the fruit was brought through phloem only. 


\section{DISCUSSION}

The heat-ring treatment by dripping hot water on the peduncle inhibited phloem transport of sugars through the pedicel without significant effect on xylem transport of water for fruit transpiration (Fig. 2). The cooperative application of the heat-ring method and the multiple chamber system enabled individual evaluations of phloem sap and xylem sap fluxes (Figs. 3 and 7) and quantitative analysis of components of water balance in the growing tomato fruit (Table 2 and Fig. 8). Fruit growth and the respective components in fruit water balance were enhanced during the light period as compared with the dark period (Figs. 5-7 and Tables 1 and 2). The major part (i.e. $84 \%$ under well-watered and $66 \%$ under water deficit) of pedicel sap flux toward the fruit $\left(\sum J_{\mathrm{Phlo}}+\sum\left(J_{\mathrm{Xy}}>0\right)\right)$ contributed to fruit growth, and transpiratory water losses from the fruit, calyx and pedicel were the minor component in fruit water balance, that is, $\sum J_{\mathrm{WF}}$ amounted to only $16 \%$ to $18 \%$ of the pedicel sap flux toward the fruit (Fig. 9). Ho et al. (1987) analyzed weekly change in calcium content in tomato fruits under the natural light and estimated that the major part (i.e. about $85 \%$ ) of sap accumulated in the fruits was brought through phloem. Our results, which were obtained by short-term experiments, verified this predominance of phloem transport in fruit sap accumulation more directly by the individual evaluations of phloem sap and xylem sap fluxes and transpiratory water loss from the pedicel and the calyx (Fig. 9). Under the well-watered condition, 70\% of sap accumulated in the fruit was brought through phloem, and this predominance of the phloem sap flux was extremely enhanced by the water deficit, inducing sap backflow from the fruit through xylem. Thus, phloem sap flux in the pedicel is suggested to be the most important component responsible for fruit expansion and fruit water balance.

Phloem sap flux has been considered to be pressure flow along sieve tubes which is supported by the respective processes of loading and reloading of sugars, osmotic influx of water to sieve tubes and unloading of sugars in sink organs (Patrick, 1997). Such phloem transport from leaves to fruits is initiated by sugar supply from photosynthesis in source leaves and is terminated by post-phloem transport of sugars into the storage cells in fruits. Therefore, photosynthesis in leaves and post-phloem transport in fruits can be rate limiting processes for accumulation of photoassimilates in the fruits. Post-phloem transport into the storage pericarp cells of tomato fruits at the stage of rapid sugar accumulation (i.e. a few weeks after anthesis) was proved to be switched to the apoplastic route which inevitably involves energydependent sugar transport across the plasma membranes of storage pericarp cells (Ruan and Patrick, 1995). This sugar transport across the plasma membranes depends on hexose/proton symport driven by $\mathrm{H}^{+}$-ATPase on the membranes (Rausch, 1991; Fisher and Oparka, 1996; Patrick and Offler, 1996). Ruan et al. (1997) have demonstrated in vitro that activity of the hexose/proton symport across the membranes can be a determinant for sugar accumulation in the storage pericarp cells under sufficient supply of hexose. Kitano et al. (1998b) also confirmed this energy-dependent sugar accumulation in intact fruit where rates of fruit growth and sugar translocation during the light period depended on fruit respiration, and were completely retarded by inhibiting fruit respiration. Furthermore, rise in fruit temperature during the light period activated fruit respiration and significantly increased the rates of fruit growth and translocation of sugars under the constant rate of leaf photosynthesis (Kitano et al., 1998a). In the well-watered plant, lighting and rise in air temperature around the whole shoot from 15 to $25^{\circ} \mathrm{C}$ activated fruit respiration as well as leaf photosynthesis (Figs. 4 and 5), which was considered to induce remarkable increases in fruit growth rate and pedicel sap flux accompanying acceleration of phloem sap flux toward the fruit (Figs. 6 and 7). These facts suggest that active fruit respiration under the well-watered condition during the light period is 
responsible for acceleration of phloem transport to fruits and fruit growth as well as leaf photosynthesis.

The water deficit treatment depressed leaf photosynthesis and fruit respiration by $50 \%$ and $40 \%$, respectively, and phloem sap flux to the fruits was reduced by $35 \%$ resultantly (Tables 1 and 2). It is notable that $65 \%$ of the phloem sap flux was sustained even under the condition cutting off water supply to roots, and the phloem transport solely contributed to the fruit growth. Concentration of solutes in sieve tubes could be increased to maintain osmotic influx of water to the sieve tubes under lowered xylem water potential as Ho et al. (1987) suggested. This osmotic adjustment is considered to support the pressure flow of phloem sap through sieve tubes even under severe water deficit.

Xylem sap flux to fruits is driven by gradient of water potential from stem to fruits. Stem water potential, as compared with fruit water potentiall, is more variable with changes in root water condition and evaporative demand. Under the respective conditions of water deficit, high salinity and high evaporative demand, stem water potentials lower than fruit water potential have been considered to induce sap backflow from fruits through xylem that sometimes leads to fruit shrinkage (Johnson et al., 1992 ; Pearce et al., 1993 ; Kitano et al., 1996b ; Guichard et al., 1999). In this study, although the fruit shrinkage did not occur under water deficit, the occurrence of xylem sap backflow was quantitatively estimated by the evaluation of fruit water balance. Furthermore, this phenomenon was confirmed by LYCH tracing. Under water stress, sap accumulated in the fruit was lost by the backflow that was equivalent to xylem sap influx to the fruit. The xylem sap backflow observed in this study demonstrates the bidirectional sap flow through xylem in the tomato pedicel, although the low continuity of xylem at the abscission zone on tomato pedicels has been estimated to be a possible barrier to sap backflow through xylem (Lee, 1988). Thus, the xylem sap flux to the fruit, as compared with the phloem sap flux, was much more affected by change in root water condition and was completely retarded by the water deficit, while the phloem sap flux was sustained by $65 \%$. The minor contribution and the unstableness observed in xylem sap flux imply the difficulty in calcium accumulation in the fruit which often induces blossom-end rot (Ho et al., 1987; Adams and Ho, 1993).

Those responses of fruit water balance and phloem sap and xylem sap fluxes elucidated in this study suggest that relative contribution of phloem transport and xylem transport to mass accumulation in tomato fruits varies with environmental conditions such as root water condition. We further confirmed quantitatively that water deficit and high salinity result in smaller tomato fruits with higher sugar concentrations and higher incidence of blossom-end rot (Ho et al., 1987, 1993, 1995 ; Mitchell et al., 1991b ; Adams and Ho, 1993). The occurrence of the xylem sap backflow suggests the complicated process of sugar and $\mathrm{Ca}^{2+}$ accumulation in the fruit under water stress. Because xylem sap backflow is probably supposed to be accompanied with outward flow of sugar and $\mathrm{Ca}^{2+}$ in fruit apoplast.

This study was supported by Grant-in-Aid for Scientific Research No. 14360154 and 11003085, Japan Society for the Promotion of Science.

\section{REFERENCES}

Adams, P., Ho, L. C. 1993. Effects of environment on the uptake and distribution of calcium in tomato and on the incidence of blossom-end rot. Plant Soil 154: 127-132.

Araki, T., Kitano, M., Eguchi, H. 1997a. Evaluation of photoassimilate flux through a pedicel. Biotronics 26 : 21-29. 
Araki, T., Kitano, M., Eguchi, H. 1997b. Respiration, sap flux, water balance and expansive growth in tomato fruit. Biotronics $26: 95-102$.

Araki, T., Kitano, M., Hamakoga, M., Eguchi, H. 1998. Analysis of growth, water balance and respiration of tomato fruits under water deficit by using a multiple chamber system. Biotronics $27: 61-68$.

Ehret, D. L., Ho, L. C. 1986. Effect of osmotic potential in nutrient solution on diurnal growth of tomato fruit. J. Exp. Bot. 37 : 1294-1302.

Fisher, D. B., Oparka, K. J. 1996. Postphloem transport: principle and problems. J. Exp. Bot. 37 : 1141-1154.

Goldschmidt, E. E., Huber, S. C. 1992. Regulation of photosynthesis by end product accumulation in leaves of plants storing starch, sucrose, and hexose sugars. Plant Physiol. 99: 1443-1448.

Grusk, M. A., Delrot, S., Ntsika, G. 1990. Short-term effects of heat-girdles on source leaves of Vicia faba: analysis of phloem loading and carbon partitioning parameters. J. Exp. Bot. 41 : 1371-1377.

Guichard, S., Gary, C., Longuenesse, J. J., Leonardi, C. 1999. Water flux and growth of greenhouse tomato fruits under summer conditions. Acta Hortic. 507: 223-229.

Ho, L. C., Adams, P., Li, X. Z., Shen, H., Andrews, J., Xu, Z. H. 1995. Responses of Ca-efficient and $\mathrm{Ca}$-inefficient tomato cultivars to salinity in plant growth, calcium accumulation and blossom-end rot. J. Hortic. Sci. 70 : 909-918.

Ho, L. C., Belda, R., Brown, M., Andrews, J., Adams, P. 1993. Uptake and transport of calcium and the possible causes of blossom-end rot in tomato. J. Exp. Bot. 44 : 509-518.

Ho, L. C., Grange, R. I., Picken, A. J. 1987. Analysis of accumulation of water and dry matter in tomato fruit. Plant Cell Environ. 10: 157-162.

Johnson, R. W., Dixon, M. A, Lee, D. R. 1992. Water relations of the tomato during fruit growth. Plant Cell Environ. 15 : 947-953.

Kitano, M., Araki, T., Eguchi, H. 1998a. Temperature dependence of postphloem transport regulated by respiration in tomato fruits. Biotronics $27: 33-39$.

Kitano, M., Araki, T., Hamakoga, M., Eguchi, H. 1998b. Environmental effects on dynamics of $\mathrm{CO}_{2}$ and $\mathrm{H}_{2} \mathrm{O}$ gas fluxes, photoassimilate translocation in tomato plants. I. Effects of irradiation and day/ night air temperature. (Japanese with English summary) Environ. Control in Biol. 36 : 159-167.

Kitano, M., Hamakoga, M., Yokomakura, F., Eguchi, H. 1996a. Interactive dynamics of fruit and stem growth in tomato plants as affected by root water condition. I. Expansion and contraction of fruit and stem. Biotronics $25:$ 67-75.

Kitano, M., Yokomakura, F., Eguchi, H. 1996b. Interactive dynamics of fruit and stem growth in tomato plants as affected by root water condition II. Relation with sucrose translocation. Biotronics 25 : 77-84.

Kramer, P. J., Boyer, J. S. 1995. Water Relations of Plants and Soils. Academic Press, San Diego, pp 495.

Lang, A. 1990. Xylem, phloem and transpiration flows in developing apple fruits. J. Exp. Bot. 41 : 645-651.

Lee, D. R. 1988. Vasculature of the abscission zone of tomato fruit : implication for transport. Can. J. Bot. 41 : 645-651.

Milburn, J. A. 1975. Pressure flow. In “Transport in Plants I. Phloem Transport” (ed. by Zimmermann, M. H., Milburn, J. A.), Encyclopedia of Plant Physiology, New Series, Vol. 1. Springer-Verlag, Berlin, p 328-353.

Mitchell, J. P., Shennan, C., Grattan, S. R. 1991a. Developmental changes in tomato fruit composition in response to water deficit and salinity. Physiol. Plant. 83 : 177-185.

Mitchell, J. P., Shennan, C., Grattan, S. R., May, D. M. 1991b. Effects of water deficit and salinity in tomato fruit yield and quality. J. Am. Soc. Hortic. Sci. 116: 215-221.

Münch, E. 1926. Dynamik der Saftstromungen. Ber. Deut. Bot. Ges. 44: 68-71.

Neales, T. F., Incoll, L. D. 1968. The control of leaf photosynthesis rate by the level of assimilate concentration in the leaf: a review of hypothesis. Bot. Rev. 34:107-125.

Patrick, J. W. 1997. Phloem unloading: sieve element unloading and post-phloem element transport. Ann. Rev. Plant Physiol. Mol. Biol. 48 : 191-222.

Patrick, J. W., Offler, C. E. 1996. Post-sieve element transport of photoassimilate in sink regions. J. Exp. Bot. 47 : 1165-1177.

Pearce, B. D., Grange, R. I., Hardrwick, K. 1993. The growth of tomato fruit. I. Effects of temperature. 
and irradiance on fruit grown in controlled environments. J. Hortic. Sci. 68 : 1-11.

Rausch, T. 1991. The hexose transporter at the plasma membrane and the tonoplast of higher plants. Physiol. Plant. 82 : 134-142.

Ruan, Y.-L., Patrick, J. W. 1995. The cellular pathway of postphloem sugar-transport in developmental tomato fruit. Planta 196 : 434-444.

Ruan, Y.-L., Patrick, J. W., Brady, C. 1997. Protoplast hexose carrier is a determinate of genotypic difference in hexose storage in tomato fruit. Plant Cell Environ. 20 : 341-349.

Smith, K. C., Magnuson, C. E., Goeschl, J. D., DeMichele, D. W. 1980. A time-dependent mathematical expression of the Münch Hypothesis of phloem transport. J. Theor. Biol. 86 : 493-505.

Tazuke, A., Sakiyama, R. 1993. Relationships between growth in volume and respiration of cucumber fruit attached on the vine. J. Jpn. Soc. Hortic. Sci. 59: 745-750.

\title{
〈和文抄録〉
}

\section{トマト果実の生長，水収支および師管と道管を通した 汁液フラックスの動的解析：短期間の水ストレスの影響}

\author{
荒木卓哉 ${ }^{1}$ 江口專 彦 $^{2}$ 和島浩 ${ }^{3} \cdot$ 吉田 敏 ${ }^{2} \cdot$ 北野雅治 ${ }^{3}$
}

${ }^{1}$ 九州大学大学院農学研究院 ${ }^{2}$ 九州大学生物環境調節センター・ ${ }^{3}$ 高知大学農学部

トマト果実の水ストレスに対する短期間の反応を調べるために, 湛液栽培区および水ストレス 栽培区に抢ける果実の肥大生長扔よび水収支について解析した。湛液区において, 小果柄を通り果 実へ流入する汁液フラックスの $84 \%$ は果実肥大に寄与し, 残りの $16 \%$ は果実およびがくからの蒸 散により消失した。トマト果実の主要な水収支項は師管液フラックスであり, 果実に集積した汁液 フラックスの 70\%を占め, 道管液フラックスに比べて水ストレスの影響は小であった. 一方, 道管 液フラックスは, 果実肥大への寄与は小さく, 水ストレスに対してょり敏感な反応を示した. 水ス トレス区で果実からの道管経由の汁液の逆流が生じ，果実へ集積した道管液フラックスの日積算 量はゼロであった。その結果, 水ストレス区では, 師部輸送が果実の肥大を維持した. 以上のこと から, 水ストレスに対する果実への師部および木部輸送の異なる反応が, 水ストレス下において小 果および高糖度をもたらすことが定量的に明らかになった。 